\title{
Effects of an Innovative Strategy to Contain Grapevine Bois Noir: Field Treatment with Resistance Inducers
}

\author{
Gianfranco Romanazzi, Sergio Murolo, and Erica Feliziani
}

Department of Agricultural, Food and Environmental Sciences, Marche Polytechnic University, via Brecce Bianche, 60131 Ancona, Italy. Accepted for publication 8 March 2013.

\begin{abstract}
Romanazzi, G., Murolo, S., and Feliziani, E. 2013. Effects of an innovative strategy to contain grapevine Bois noir: Field treatment with resistance inducers. Phytopathology 103:785-791

Grapevine Bois noir $(\mathrm{BN})$ is a phytoplasma disease that is widespread in most viticultural regions of the world, and it can result in heavy reductions to yields and grape juice quality. At present, there is no effective strategy to reduce the incidence of $\mathrm{BN}$-infected grapevines. However, phytoplasma-infected plants can recover through spontaneous or induced symptom remission. Five elicitors (chitosan, two glutathioneplus-oligosaccharine formulations, benzothiadiazole, and phosetyl-Al)

inductions were obtained with benzothiadiazole and the two glutathioneplus-oligosaccharine formulations. The plants that recovered naturally or following the elicitors showed qualitative and quantitative parameters of production no different from healthy plants. In another vineyard, diseased plants showed reduced shoot length and production compared with healthy plants, and there were no negative effects on these parameters for grapevines sprayed with a glutathione-plus-oligosaccharine formulation. The application of resistance inducers promoted the recovery of $\mathrm{BN}$ infected grapevines with no adverse effects on the plants. Therefore, grapevine can be used as a model species to test this innovative strategy to contain phytoplasma diseases.
\end{abstract} were applied weekly to the canopy of BN-infected 'Chardonnay' grapevines from early May to late July. The best and most constant recovery
Additional keywords: Vitis vinifera.
Stolbur phytoplasma are classified into the 16SrXII-A subgroup, and they are the agent of the grapevine (Vitis vinifera) disease known as Bois noir (BN). Outbreaks of $\mathrm{BN}$ are becoming ever more frequent in several countries in Europe and in the Mediterranean area (21). Furthermore, it has spread through South Africa, Western Asia, Australia, South America, and North America $(21,22)$. Even if $\mathrm{BN}$ is not considered a quarantine disease by the European Plant Protection Organization, as Flavescence dorée (FD) is, BN has a heavy impact on viticulture production (11).

The impossibility of culturing phytoplasma in vitro has greatly delayed the development of methods to control these pathogens, although recent findings for the growth of phytoplasma have opened new possibilities (7). Even preventive measures such as the use of healthy propagating materials and treatments against the leafhopper vectors have not been effective for the reduction of $\mathrm{BN}$ incidence. This is mainly because the $\mathrm{BN}$ vector lives on herbaceous plants, from which it acquires the stolbur phytoplasma, and only occasionally feeds on grapevine (21). For BN, the application of roguing to symptomatic plants does not contribute to a reduction in its epidemiology, because the infected grapevines are not a source of infection (28).

An intriguing phenomenon that can occur in grapevine infected by phytoplasma is "recovery", a spontaneous remission of the disease symptoms in plants that previously showed them (4). In grapevine, this natural phenomenon has been observed for several varieties and viticultural regions, at different levels. Several investigations have shown that the remission of the symptoms can be promoted by exposing the grapevine to abiotic stress, such as uprooting of the plant followed by immediate transplanting (28), by partial uprooting or pulling of the plant (32), and by agronomic practices such as pruning and pollarding (2). One of the

Corresponding author: G. Romanazzi; E-mail address: g.romanazzi@univpm.it

http://dx.doi.org/10.1094/PHYTO-01-13-0031-R

(C) 2013 The American Phytopathological Society few practical chances to reduce the number of symptomatic plants is through an increase in host resistance (33). Recovery appears to be linked to the activity of particular compounds, such as plant secondary metabolites. In particular, a higher activity of $\mathrm{NAD}(\mathrm{P}) \mathrm{H}$ peroxidases of leaf-cell plasma membranes, and an increase of jasmonic acid in concomitance with a decline in salicylic acid, have been recorded in recovered plants, which indicates that this phenomenon is related to systemic acquired resistance (SAR) $(19,25,26,29)$. SAR is a nonspecific form of disease resistance in plants that can be activated by several nonspecific inducers (elicitors). This process is mediated by salicylic acid $(36,37)$ and it appears to involve a specific set of genes that code for several pathogenesis-related proteins.

Because there are no effective and direct means to reduce the incidence of $\mathrm{BN}$, an innovative and promising approach consists of spraying the plant canopy with resistance inducers to enhance the number of plants with symptom remission. The use of resistance inducers was first tested on phytoplasma-diseased plants in the weedy hosts, such as with Arabidopsis thaliana (3), and then Catharanthus roseus (5), Chrysanthemum carinatum $(9,10)$, and Lycopersicon esculentum (39). Pioneer investigations on woody plants have provided the first results on the effectiveness of these elicitors in containing grapevine $\mathrm{BN}$ following their canopy application (30).

In the present study, the effects of five elicitors were evaluated through their application to the canopy of $\mathrm{BN}$-infected grapevines, with the recording of the incidence of the remission of disease symptoms and the impact on various quantitative and qualitative yield parameters. The effect of one of the tested elicitors, based on glutathione and oligosaccharines, on shoot length and plant production was also investigated.

\section{MATERIALS AND METHODS}

Field trials. The study was carried out in two commercial vineyards of 'Chardonnay' in the Marche region, central-eastern Italy: 
vineyard 1, at Loreto (2009-10), and vineyard 2, at Montalto delle Marche (2010) (Table 1). Neither of these vineyards was irrigated, and they had fertilizers distributed in winter and additional green pruning applied in spring and summer, as are the normal practices for these areas. An integrated pest management program was applied to control the main fungal diseases (downy mildew, powdery mildew, and gray mold) and insects (moths). Pesticides were only used under pest-outbreak conditions, although these excluded chemicals that might interfere with the experimental system (e.g., phosetyl-Al).

Effectiveness of elicitors in the control of $\mathbf{B N}$ infections. The five compounds tested in the field trials in vineyard 1 were chitosan (5 kg/ha; Chito Plant; ChiPro GmbH, Germany), phosetyl-Al ( $3 \mathrm{~kg} / \mathrm{ha}$; Aliette; Bayer Crop Science, Germany), two different formulations of glutathione plus oligosaccharines (each at 4 liters/ha; Kendal [GO1]; Valagro, Italy; and Olivis [GO2]; Agrisystem, Italy), and benzothiadiazole $(0.2 \mathrm{~kg} / \mathrm{ha}$; Bion; Syngenta Crop Protection, Switzerland). In vineyard 2, the elicitor tested was the GO1 glutathione-plus-oligosaccharines formulation (4 liters/ha). The formulations were dissolved in tap water and were sprayed on the canopy of the $\mathrm{BN}$-infected grapevines. The treatments were applied as 13 weekly applications (from the beginning of May to the end of July). The elicitors were applied by spraying a volume equivalent to 1,000 liters/ha using a motorized backpack sprayer (Honda GX 25; Tokyo). The effectiveness of these elicitors in the control of $\mathrm{BN}$ was expressed as the percentages of recovered plants that had been symptomatic during the year before the applications, according to the assessments carried out after the end of the treatments (end of July, August, and mid-September). The plants were considered symptomatic even if mild disease symptoms were found on leaves and grape clusters in one of these assessments. When there were no clear symptoms, leaf samples were taken and analyzed, as reported below.

Molecular detection of phytoplasma. For disease assessments in both of the vineyards, leaf samples were collected from the plants with doubtful symptoms and from randomly selected grapevines among the symptomatic, recovered, and healthy plants (30 each). These were subjected to molecular analyses. Total DNA was extracted from $1 \mathrm{~g}$ of leaf petioles using DNeasy Plant mini kits (Qiagen, Hilden, Germany). The amplifications were performed in a programmable Bio-Rad Cycler (Bio-Rad, Hercules, CA) in a final reaction volume of $50 \mu$, which contained 50 ng of DNA template, $50 \mathrm{ng}$ of each primer, $125 \mu \mathrm{M}$ each dNTP (Promega Corp., Madison, WI), 1 U of Taq DNA polymerase (Promega Corp.), and the $1 \times$ polymerase chain reaction (PCR) buffer with $1.5 \mathrm{mM} \mathrm{MgCl}_{2}$, according to the PCR conditions described by Endeshaw et al. (11). The finer characterization of the phytoplasma was carried out by amplifying and digesting a portion of the tuf gene (20).

Shoot length measures. In vineyard 2, the plants that were both symptomatic and symptomless in the previous year were sprayed with the elicitor GO1, as reported above, and compared with untreated symptomatic and symptomless plants as the controls. The lengths of the shoots were recorded on 27 May and on
6 and 12 June 2010. All of the shoots of 10 randomly selected grapevines per replicate were measured for each symptom status in the previous year: (i) symptomatic and (ii) healthy plants treated with GO1 and untreated (iii) symptomatic and (iv) healthy plants.

Quantitative yield parameters. In vineyard 1, the grape berries from each plant across all of the treatments were separately harvested on 3 September 2010 for the healthy, symptomatic, and recovered grapevines. The total production (kilograms per plant) was determined using a digital dynamometer (Handyscale; Bonso Electronics, Hong Kong, China), and the numbers of healthy and dehydrated clusters were recorded and expressed as percentages. The berry weight (grams) was measured using an electronic balance (model BC 500; ORMA, Milan, Italy) and the berry diameter (millimeters) using digital calipers (Metrica, San Donato Milanese, Italy). Both of these sets of data were calculated as the means of 10 berries per grape cluster per elicitor. In vineyard 2, the production of 10 randomly selected plants per symptom status and treatment (as above) was recorded at the harvest (7 September 2010), for each replicate.

Qualitative yield parameters. The analysis of qualitative parameters was carried out on juice samples from the grape berries collected in vineyard 1 in 2010 . In particular, the samples from each healthy, symptomatic, and recovered plant in 2010 were analyzed. Each juice sample was obtained by blending $150 \mathrm{~g}$ of berries. In all, $\approx 25 \mathrm{ml}$ of filtered juice was collected and centrifuged at 4,200 $\times g$ for $5 \mathrm{~min}$ in 50-ml Corex tubes. The soluble solids content was determined using a Brix refractometer (Atago, Tokyo), and the titratable acidity was measured by titration with $\mathrm{NaOH}$ to an end point $\mathrm{pH}$ of 8.2, with the $\mathrm{pH}$ determined using a pH meter (model HI222; Hanna Instruments, Eureka, CA).

Experimental design. The experiment set up in vineyard 1 consisted of three completely randomized blocks, with 12 replicates (single plants) in 2009 and 21 in 2010 for each elicitor. To assess the rate of spontaneous recovery, the same numbers of symptomatic plants were used as untreated controls. In vineyard 2, the experimental field was divided into three blocks, half of each sprayed with GO1 and half left as the untreated control (245 grapevines each, $\approx 30 \%$ of which had shown disease symptoms in 2009).

Statistical analysis. The data on effectiveness of resistance inducers were expressed as percentages of recovered plants. The mean disease incidences in 2009 and 2010 were analyzed together with the data recorded for 2007 and 2008 with the same treatments in another vineyard (30), and the means were compared by Duncan's multiple range tests at $P \leq 0.05$ using the Statistica package (Statsoft Inc., Tulsa, OK). Moreover, the treatments were subjected to rank analysis $(6,31)$. The data for the shoot length, quantitative and qualitative parameters were compared by Tukey's honestly significant difference test using the Statistica package (Statsoft Inc.) at $P \leq 0.05$.

\section{RESULTS}

Effectiveness of elicitors in the control of $\mathbf{B N}$ infections. The symptomatic grapevines were characterized by leaf rolling associ-

TABLE 1. Properties of the commercial vineyards where the study was carried out

\begin{tabular}{lll}
\hline Property & \multicolumn{1}{c}{ Vineyard 1 } & Vineyard 2 \\
\hline Year of trial & $2009-10$ & 2010 \\
Region & Marche & Marche \\
Location & Loreto & Montalto \\
Geographic coordinates & $43^{\circ} 26^{\prime} 10^{\prime \prime} 68 \mathrm{~N} ; 13^{\circ} 36^{\prime} 38^{\prime \prime} 52 \mathrm{E}$ & $42^{\circ} 59^{\prime} 26^{\prime \prime} 88 \mathrm{~N} ; 13^{\circ} 36^{\prime} 36^{\prime \prime} 36 \mathrm{E}$ \\
Altitude (m) & 170 & 513 \\
Plant spacing (m) & 3 by 1.5 & 1.3 by 3 \\
Trellis system & Single curtain & Single curtain \\
Year of planting & 1989 & 2005 \\
Cultivar & Chardonnay & Chardonnay \\
Rootstock & Kober 5BB & Kober 5BB \\
Initial Bois noir incidence & $10 \%$ & $30 \%$ \\
\hline
\end{tabular}


ated with chlorosis, necrosis of leaf veins and laminas, flower abortion and shriveling of berries, and a partial lack of lignification of canes; in a few cases, the leaf blades of symptomatic plants detached, leaving the petiole on the plant. In vineyard 1, in 2009 , all of the treatments significantly increased the number of recovered plants compared with the untreated control (Table 2). In 2010, there were no significant differences between the control and all of the active treatments. Considering the variability of the plant responses to treatment over time, the data for 2009 and 2010 were analyzed together, along with the data obtained in an initial study that was carried out in 2007 and 2008 with the same compounds, although in another vineyard (30). From the means thus obtained, it emerged that there were constant high recovery rates in these 4 years of field trials in the plants sprayed with benzothiadiazole, GO1, and GO2. These elicitors enhanced the rate of recovery over the average of $50 \%(56.7,53.9$, and $50.8 \%$, respectively) compared with $26.4 \%$ recorded for the control recovered plants (Table 2). Tendencies toward reductions in the symptomatic grapevines were also recorded for the chitosan and phosetyl-Al applications, although these were less effective in terms of the mean increased incidence of recovery (35.1 and $36.9 \%$, respectively) when compared with the natural rate. A more direct analysis of the degree of comparative effectiveness for the induction of recovery was obtained through the application of rank analysis (Table 3). This data analysis confirmed that the control had the highest sum of ranks $(=20$; therefore, the least effective as a treatment for recovery induction), with chitosan and phosetyl-Al showing slightly lower values (17 and 19, respectively), while the lower sum of ranks for benzothiadiazole, GO1, and GO2 showed that they were largely as effective as each other $(=7,8$, and 10 , respectively). Across all of these trials, none of the treatments induced phytotoxic effects in the grapevines.

Molecular detection of phytoplasma. A good correlation was recorded between the symptom status (as symptomatic, recovered, or healthy) assessed in September 2010 in vineyard 1 and the results of the molecular detection carried out on the leaf samples collected in same period (Fig. 1A). For the recovered and healthy plants, no amplicons were generated in PCR with the ribosomal-specific primer pair fStol/rStol, which identified a 500-bp fragment in 29 of 30 symptomatic plants tested. The finer molecular characterization carried out for the tuf gene by HpaIIrestriction fragment length polymorphism analysis allowed the detection of phytoplasma infection induced by the tuf-b type (Fig. $1 B)$. In both the naturally and elicitor-induced recovered grapevines, PCR testing carried out under the same conditions as above failed to detect phytoplasma.

Shoot length measures. In vineyard 2, for all three of the assessments in May and June 2010, there were no significant effects of GO1 application on the shoot lengths for either the symptomatic or the healthy plants (Fig. 2). The shoot lengths of the plants that had shown disease symptoms in the previous year were significantly lower $(P \leq 0.05)$ than for the healthy plants, both without and with the GO1 treatments, at all three of the evaluations.

Quantitative yield parameters. Under all of the treatments, the percentages of dehydrated grape clusters were significantly higher $(P \leq 0.05)$ in the plants that showed BN symptoms in 2010 compared with both the healthy and recovered plants (Fig. 3A). The highest mean percentage of dehydrated grape clusters was recorded for the control plots $(32.0 \%)$. The treatment with the elicitors had a tendency toward reductions in this incidence of dehydrated grape clusters, with values $\approx 40 \%$ lower in symptomatic plants treated with benzothiadiazole, GO1, and GO2 (percentages of dehydrated grape clusters: 17.6, 22.0, and 18.8\%, respectively) compared with the control (Fig. 3A). For the recovered grapevines, the incidence of dehydrated grape clusters was negligible $(<3 \%)$, and was not significantly different across the treatments.

The grape production of the plants that showed recovery following the treatments with the elicitors was not significantly different $(P \leq 0.05)$ from that for the healthy plants (Fig. 3B). However, the grape production of the symptomatic plants was generally $\approx 50 \%$ of that for the recovered and healthy plants, with no significant differences among the active treatments. Here, significant reductions in the grape production in the treated symptomatic plants compared with the recovered plants treated with the same active ingredient were only observed for GO1 and GO2, in contrast with benzothiadiazole, the application of which induced less evident reductions in grape production comparing symptomatic versus recovered plants (21\%) (Fig. 3B).

The symptomatic versus recovered plants also showed a reduction in the berry diameters $(\approx 15 \%)$ and berry weights (from 24 to $35 \%$ ), with no differences between the symptomatic plants (Fig. $3 \mathrm{C}$ and D).

In vineyard 2 , the grape production of the symptomatic plants was significantly lower compared with the healthy plants, and it was not affected by the treatment with GO1. In detail here, the

TABLE 3. Effects of the five elicitors on the induction of recovery for Bois noir-infected grapevines in the trials carried out in vineyard 1 (Loreto) in 2009 to 2010 , with the effectiveness of the treatments shown according to rank analysis $^{\mathrm{z}}$

\begin{tabular}{lccccc}
\hline & \multicolumn{5}{c}{ Rank } \\
\cline { 2 - 5 } Treatment & 2007 & 2008 & 2009 & 2010 & Sum of ranks \\
\hline GO1 & 3 & 1 & 1 & 3 & 8 \\
GO2 & 2 & 3 & 2 & 3 & 10 \\
Benzothiadiazole & 1 & 2 & 3 & 1 & 7 \\
Phosetyl-Al & 4 & 5 & 4 & 6 & 19 \\
Chitosan & 5 & 4 & 4 & 5 & 18 \\
Control & 6 & 6 & 6 & 2 & 20 \\
\hline
\end{tabular}

${ }^{\mathrm{z}}$ Data from the previous 2 years (2007 and 2008) have been added from Romanazzi et al. (30) for improved trend analysis of the effectiveness of these elicitors over these 4 years (see main text); BTH = benzothiadiazole.

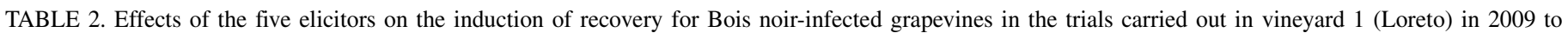
$2010^{\mathrm{x}}$

\begin{tabular}{|c|c|c|c|c|c|}
\hline \multirow[b]{2}{*}{ Treatment } & \multicolumn{4}{|c|}{ Recovered plants $(\%)^{\mathrm{y}}$} & \multirow[b]{2}{*}{4 -Year mean $\pm \mathrm{SE}^{\mathrm{Z}}$} \\
\hline & 2007 & 2008 & 2009 & 2010 & \\
\hline GO1 & $71.4 \mathrm{a}$ & $57.1 \mathrm{a}$ & $58.4 \mathrm{a}$ & $28.6 \mathrm{~b}$ & $53.9 \pm 9.0$ \\
\hline $\mathrm{GO} 2$ & $74.5 \mathrm{a}$ & $50.0 \mathrm{ab}$ & $50.0 \mathrm{a}$ & $28.6 \mathrm{~b}$ & $50.8 \pm 9.4$ \\
\hline Benzothiadiazole & $79.5 \mathrm{a}$ & $53.3 \mathrm{ab}$ & $41.7 \mathrm{ab}$ & $53.4 \mathrm{a}$ & $56.7 \pm 7.8$ \\
\hline Phosetyl-Al & $65.7 \mathrm{ab}$ & $28.6 \mathrm{bc}$ & $33.3 \mathrm{~b}$ & $20.0 \mathrm{~b}$ & $36.9 \pm 10.0$ \\
\hline Chitosan & $48.6 \mathrm{bc}$ & $31.2 \mathrm{bc}$ & $33.3 \mathrm{~b}$ & $27.3 \mathrm{~b}$ & $35.1 \pm 4.7$ \\
\hline Control & $37.5 \mathrm{c}$ & $23.1 \mathrm{c}$ & $8.3 \mathrm{c}$ & $36.8 \mathrm{ab}$ & $26.4 \pm 6.9$ \\
\hline
\end{tabular}

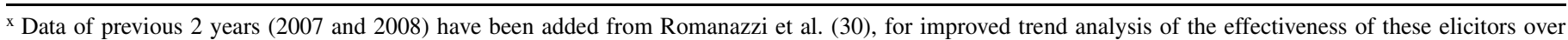
these four years (see main text).

y Values followed by different letters are significantly different within the columns, according to Duncan's multiple range tests $(P \leq 0.05)$.

z $\mathrm{SE}=$ standard error. 
control symptomatic plants produced a mean of $2.0 \mathrm{~kg}$ of grape berries per plant (versus $8.8 \mathrm{~kg}$ for healthy plants; $78 \%$ reduction), while the GO1-treated grapevines with $\mathrm{BN}$ symptoms produced a mean of $2.8 \mathrm{~kg}$ of grape berries per plant (versus $8.1 \mathrm{~kg}$ for healthy plants; $66 \%$ reduction).

Qualitative yield parameters. Analysis of the main qualitative production parameters were carried out for the grape juice from
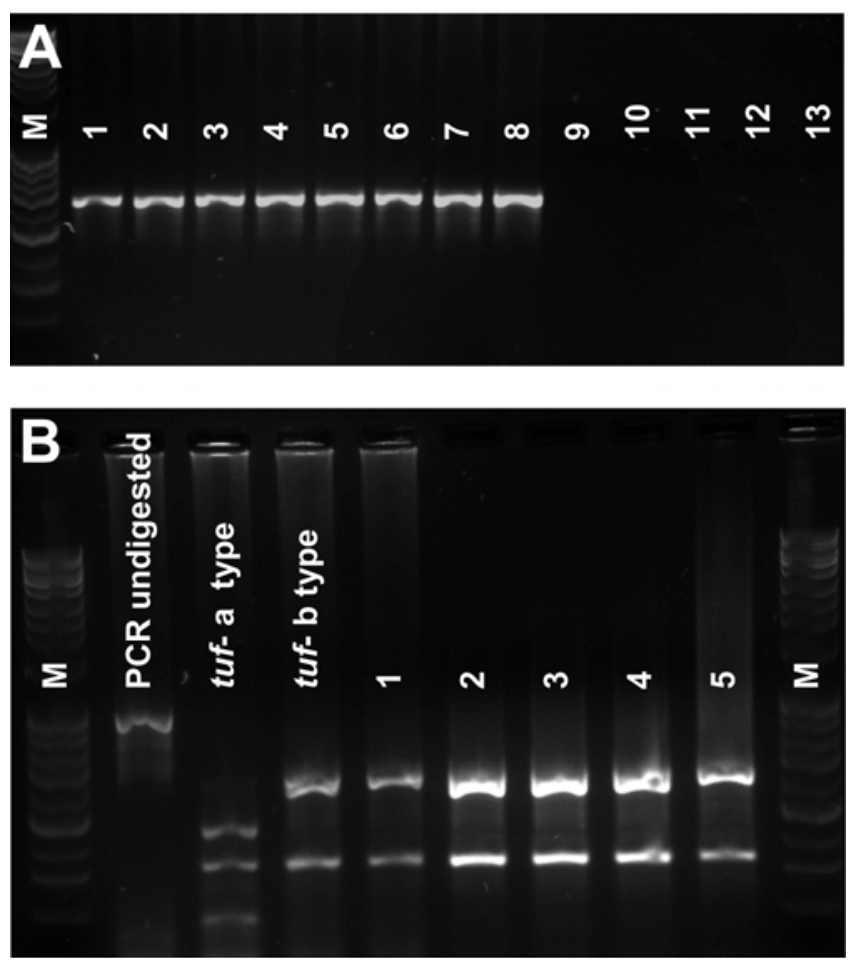

Fig. 1. A, Polymerase chain reaction amplification of total DNA with the fStol/rStol primer pair for the samples extracted from lanes 2 to 8 , symptomatic; lanes 9 and 10, recovered; and lanes 11 and 12, healthy grapevines. Lane M, BenchTop 1-kb DNA Ladder (Promega Corp.); lane 1, positive control; lane 13, water control. B, Molecular characterization carried out for the tuf gene by HpaII restriction fragment length polymorphism analysis. All of the samples (lanes 1 to 5) showed the same pattern as the tuf-b type reference strain. Lane M, BenchTop 1-kb DNA Ladder (Promega Corp.).

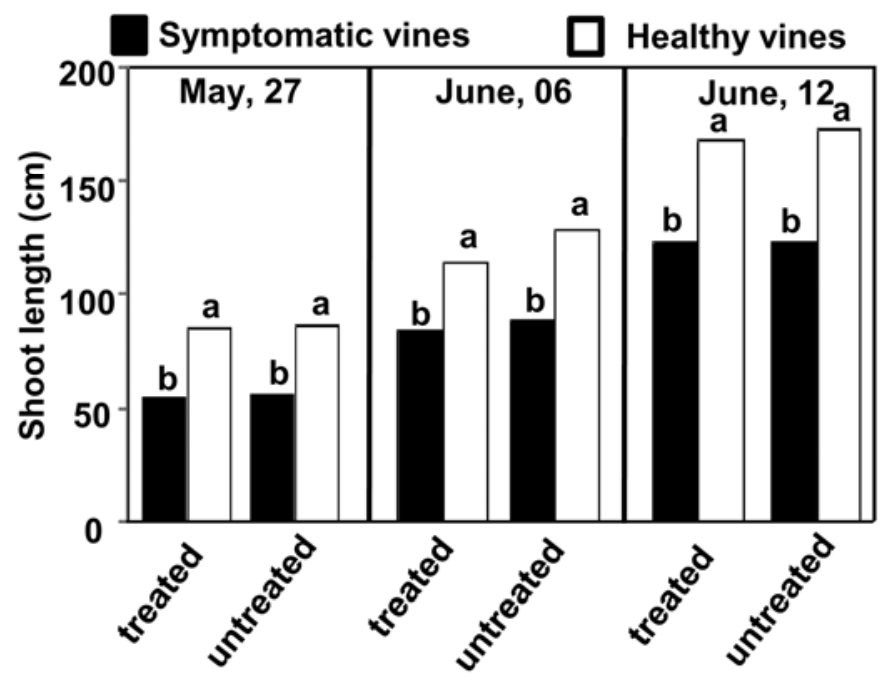

Fig. 2. Mean shoot lengths of 10 symptomatic and healthy grapevines without (untreated) and with (treated) weekly treatments with glutathione + oligosaccharines from the beginning of May to the end of July, as recorded in vineyard 2 (Montalto) on 27 May and 6 and 12 June 2010. Different letters indicate that the values are significantly different within each date panel, according to Tukey's honestly significant difference, at $P \leq 0.05$. $\square$ Symptomatic $\square$ Recovered $\square$ Healthy vines

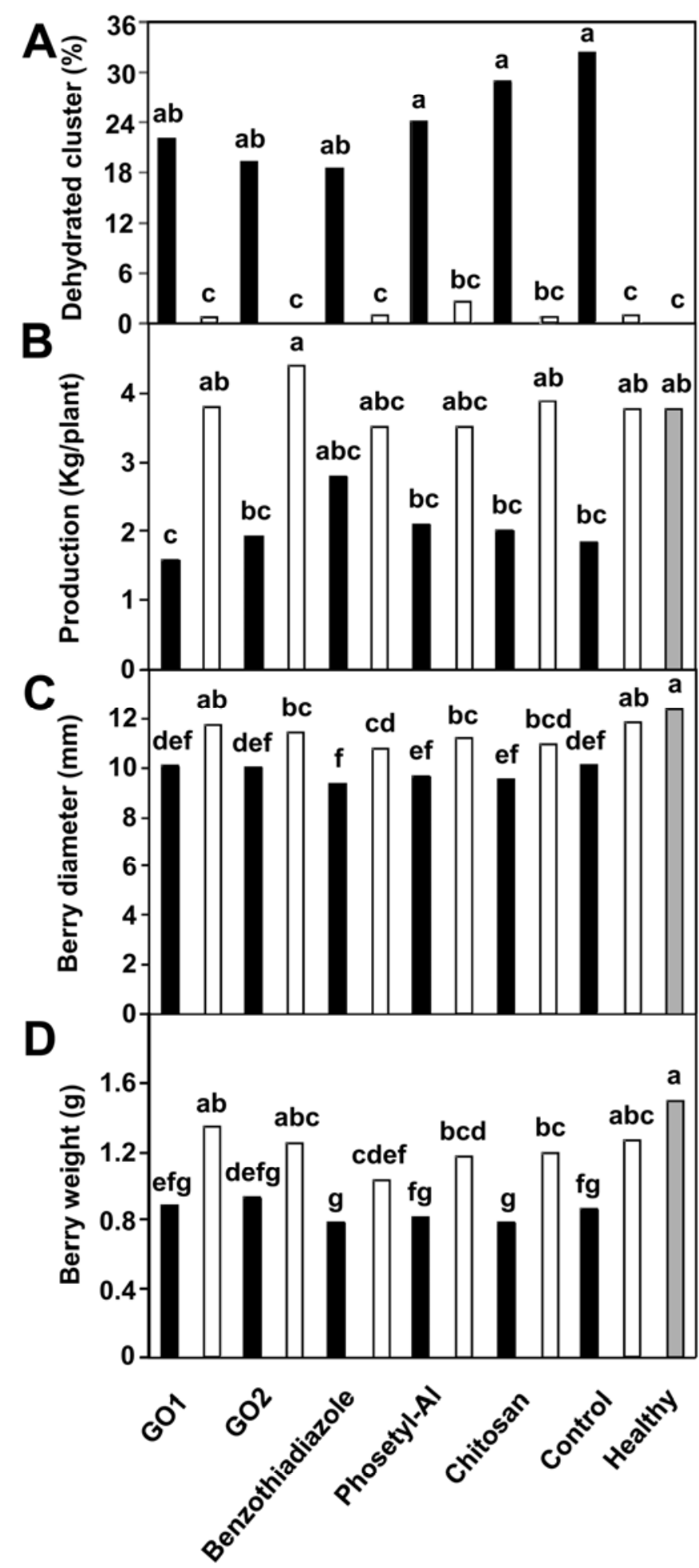

Treatment

Fig. 3. Effects on the quantitative yield parameters of the induction with the five elicitors (as indicated) and the water control, following weekly spraying on the grapevine canopy from the beginning of May to the end of July 2010, in the field trial carried out at vineyard 1 (Loreto). Symptomatic and recovered grapevines are shown, along with untreated healthy grapevines (as indicated). A, Mean relative levels of dehydrated grape clusters. B, Total grape production. C, Mean berry diameters. D, Mean berry weights. Different letters indicate that the values are significantly different according to Tukey's honestly significant difference, at $P \leq 0.05$. 
vineyard 1: titratable acidity, $\mathrm{pH}$, sugar content, and Brix degree. Although none of these parameters were significantly different between the symptomatic and recovered plants within each treatment, they did demonstrate some specific differences between grape juice from the elicitor-treated symptomatic plants and the healthy plants. The grape juice from the healthy plants showed titratable acidity that was the same as the symptomatic and recovered untreated controls (Table 4). The grape juice from symptomatic plants sprayed with GO1 and benzothiadiazole showed significantly higher titratable acidity than that from the control symptomatic plants and the healthy plants. The grape juice from the same inducer treatments, GO1 and benzothiadiazole, also showed malic acid levels that were significantly higher than seen for the grape juice from the healthy plants. Finally, the soluble solids and the Brix degree of the grape juice were significantly lower for the symptomatic plants treated with chitosan and benzothiadiazole compared with the healthy plants (Table 4).

\section{DISCUSSION}

$\mathrm{BN}$ is a serious concern for the viticulture of large areas of the world, and it is more difficult to control than FD $(21,22)$. BN can dramatically reduce qualitative and quantitative yields, especially of susceptible grapevine cultivars such as Chardonnay $(11,19)$. As for all phloem-restricted microorganisms, there are no effective control measures, and the strategy to contain damage is at present based mainly on "prevention" and, hence, on the use of phytoplasma-free propagating material. Thus, empowering the natural symptom remission of $\mathrm{BN}$-infected grapevines represents an innovative strategy that deserves deeper investigation. For these reasons, one of the most recent choices is to promote plant resistance (33), which today is becoming an even more popular way to control plant diseases as part of integrated pest management programs. At present, there have been a few successful studies on the activity of benzothiadiazole (which is a photostable form of salicylic acid, a plant signal mediator in SAR) for Xdisease phytoplasma in A. thaliana and for chrysanthemum yellows phytoplasma, and on indole-3-acetic acid and indole-3butyric acid applied to in vitro-grown periwinkle shoots infected with different 'Candidatus Phytoplasma' spp. under controlled conditions $(3,8,9)$. Recently, application of salicylic acid was shown to be effective in reducing potato purple top phytoplasma infections in L. esculentum (39).

In the present study, five elicitors were applied to BN-infected grapevines in field trials according to an intense treatment schedule (13 weekly applications per year). Following these experimental conditions, the number of recovered Chardonnay plants was consistently improved by the treatment with the resistance inducers. Although the effectiveness of the individual inducers examined here varied over the 4 years of these trials, all of them promoted recovery-inducing activity. The best results were obtained with benzothiadiazole, GO1, and GO2, which decreased the incidence of symptomatic plants by $\approx 50 \%$. Benzothiadiazole, which is also known as BTH and acibenzolar-S-methyl, can induce resistance against a broad spectrum of pathogens and pests in many plant species $(36,37)$. Benzothiadiazole does not appear to have in vitro antimicrobial properties here but, rather, as for the case of chrysanthemum yellows phytoplasma, it appears to promote delay in the pathogen multiplication and symptom development, without affecting the vector transmission efficiency $(9,27)$. Moreover, because it mimics the action of salicylic acid, benzothiadiazole can induce a range of SAR-associated genes and pathogenesis-related proteins (36). However, in recent studies, benzothiadiazole has been shown to have good antimicrobial activity on several decay-causing fungi, such as Botrytis cinerea, Rhizopus stolonifer, Monilinia laxa, and Alternaria alternata (12).

Together with benzothiadiazole, effective recovery induction was provided by both of the formulations containing gluthatione and oligosaccharines (GO1 and GO2). The functions proposed for glutathione in higher plants include the storage and transport of reduced sulfur (which is a protein reductant), a protective role in cellular metabolism, and the removal of free radicals. In particular, thiol-disulfide status appears to be crucial for the expression of defense genes that encode the enzymes of phytoalexin and lignin biosynthesis, as well as for the stimulation of genes that encode cell-wall components $(15,38)$. An accumulation of defense-related transcripts (PR1, MPK1, and TGA1) was observed in Arabidopsis plants treated with GO1 (34).

In our trials, chitosan and phosetyl-Al showed relatively low activities for the reduction in the number of symptomatic plants, with values that were only slightly higher than for the control. D'Amelio et al. (10) observed a delay in symptom development on chrysanthemum infected by ' $\mathrm{Ca}$. P. asteris' after chitosan application. Chitosan is a natural biopolymer with antimicrobial properties, and it is an elicitor of plant resistance against fungi, bacteria, and viruses, because it can produce a film on treated tissue $(1,18,31)$. Treatments with resistance inducers that were carried out on phytoplasma-infected $C$. roseus showed different responses for the plants sprayed with phosetyl-Al and chitosan (5), with phosetyl-Al being more effective. Although the pathosystem is different, overall, in our trials, the effectiveness of chitosan and phosetyl-Al was not significantly different.

The recovered status induced by the five elicitors used in this study was not based only on leaf symptom remission but also included grape production, estimated as the percentages of dehydrated grape clusters. In the plants sprayed with the most effective resistance inducers that were still symptomatic, there was a tendency toward reductions in the percentages of the dehydrated grape clusters compared with the untreated plants and, therefore,

TABLE 4. Effects of the five elicitors on the must qualitative parameters in the field trial carried out in vineyard 1 (Loreto, Marche) in 2010

\begin{tabular}{|c|c|c|c|c|c|}
\hline \multirow[b]{2}{*}{ Treatment } & \multirow[b]{2}{*}{ Status } & \multicolumn{4}{|c|}{ Must qualitative parameter ${ }^{\mathrm{Z}}$} \\
\hline & & Titratable acidity (g/liter) & Malic acid (g/liter) & Soluble solids (g/liter) & Brix degree $\left({ }^{\circ}\right.$ Brix $)$ \\
\hline \multirow[t]{2}{*}{ GO1 } & Symptomatic & $9.36 \pm 0.40 \mathrm{ab}$ & $4.20 \pm 0.19 \mathrm{ab}$ & $194.31 \pm 9.78 \mathrm{ab}$ & $19.19 \pm 0.84 \mathrm{ab}$ \\
\hline & Recovered & $7.95 \pm 0.24 \mathrm{bc}$ & $3.67 \pm 0.04 \mathrm{abc}$ & $209.34 \pm 4.05 \mathrm{ab}$ & $20.54 \pm 0.27 \mathrm{ab}$ \\
\hline \multirow[t]{2}{*}{$\mathrm{GO} 2$} & Symptomatic & $8.72 \pm 0.49 \mathrm{abc}$ & $3.60 \pm 0.06 \mathrm{abc}$ & $199.62 \pm 7.23 \mathrm{ab}$ & $19.59 \pm 0.66 \mathrm{ab}$ \\
\hline & Recovered & $8.16 \pm 0.51 \mathrm{abc}$ & $3.65 \pm 0.35 \mathrm{abc}$ & $207.07 \pm 7.85 \mathrm{ab}$ & $20.27 \pm 0.69 \mathrm{ab}$ \\
\hline \multirow[t]{2}{*}{ Benzothiadiazole } & Symptomatic & $9.98 \pm 2.19 \mathrm{a}$ & $4.56 \pm 0.99 \mathrm{a}$ & $183.84 \pm 30.98 b$ & $18.19 \pm 2.79 b$ \\
\hline & Recovered & $8.12 \pm 0.91 \mathrm{abc}$ & $3.38 \pm 0.61 \mathrm{abc}$ & $202.68 \pm 11.92 \mathrm{ab}$ & $19.96 \pm 1.01 \mathrm{ab}$ \\
\hline \multirow[t]{2}{*}{ Phosetyl-Al } & Symptomatic & $8.51 \pm 0.92 \mathrm{abc}$ & $3.80 \pm 0.95 \mathrm{abc}$ & $203.30 \pm 3.23 \mathrm{ab}$ & $19.97 \pm 0.24 \mathrm{ab}$ \\
\hline & Recovered & $8.00 \pm 0.28 b c$ & $3.64 \pm 0.30 \mathrm{abc}$ & $209.15 \pm 4.00 \mathrm{ab}$ & $20.41 \pm 0.39 \mathrm{ab}$ \\
\hline \multirow[t]{2}{*}{ Chitosan } & Symptomatic & $9.27 \pm 1.55 \mathrm{abc}$ & $3.89 \pm 0.70 \mathrm{abc}$ & $182.95 \pm 11.01 \mathrm{~b}$ & $18.19 \pm 1.01 \mathrm{~b}$ \\
\hline & Recovered & $8.26 \pm 0.95 \mathrm{abc}$ & $3.20 \pm 0.66 \mathrm{bc}$ & $200.66 \pm 8.18 \mathrm{ab}$ & $19.71 \pm 0.58 \mathrm{ab}$ \\
\hline \multirow[t]{2}{*}{ Control } & Symptomatic & $7.41 \pm 0.64 \mathrm{c}$ & $3.68 \pm 0.44 \mathrm{abc}$ & $200.83 \pm 14.54 \mathrm{ab}$ & $19.46 \pm 1.63 \mathrm{ab}$ \\
\hline & Recovered & $8.06 \pm 0.42 b c$ & $3.92 \pm 0.66 \mathrm{abc}$ & $199.21 \pm 18.74 \mathrm{ab}$ & $19.61 \pm 1.60 \mathrm{ab}$ \\
\hline Healthy & $\ldots$ & $7.38 \pm 1.25 \mathrm{c}$ & $2.85 \pm 0.64 \mathrm{c}$ & $216.27 \pm 10.42 \mathrm{a}$ & $21.07 \pm 0.81 \mathrm{a}$ \\
\hline
\end{tabular}

z Values followed by different letters are significantly different within the columns, according to Tukey's honestly significant difference, at $P \leq 0.05$. 
the disease symptoms were milder compared with the less effective elicitors tested and the control. Although the disease symptoms did not disappear in these plants, the magnitude of the disease effects on the grape clusters was reduced and there were positive effects on production, which demonstrates what a grower can expect from these kinds of treatments.

For the recovered versus healthy plants, overall, there were no significant differences for mean grape production and for all of the qualitative parameters tested. This does not support the hypothesis that the metabolic changes induced in planta by such treatments with SAR inducers can divert energy and carbon resources from vital processes, which would be expected to reduce plant productivity. Indeed, benzothiadiazole induction of SAR has been negatively correlated to crop yield in wheat and cauliflower, reportedly because of this proposed fitness cost $(14,16,35,36)$. On the other hand, chitosan and benzothiadiazole applications did not reduce crop yields in bean $(17,18)$. These last data are supported by the data from vineyard 2 in the present study, where GO1 was applied: the shoot lengths and the total production in the healthy-but-treated vines were not significantly different from the healthy untreated plants. Moreover, none of the elicitors applied on the $\mathrm{BN}$-infected grapevines in vineyard 1 showed any effects on the qualitative parameters for the recovered plants, as has already been reported by Garau et al. (13).

In the samples from the recovered plants collected in the two vineyards here, the molecular tests on the leaf veins failed to reveal the presence of phytoplasma, which is in agreement with studies reported from several Italian and German areas for such recovered $\mathrm{BN}$-infected and FD-infected plants $(21,23,30,32)$. Moreover, we saw good correlation between the presence or absence of leaf and grape-cluster symptoms with the data from the molecular analysis. The tuf gene characterization carried out for vineyard 1 allowed the detection of tuf-b type in most of the samples analyzed, which was the prevalent tuf type recorded in the Marche region (24).

The data obtained in our field experiments has allowed us to further define the activities of the plant defense inducers tested for their abilities to potentiate induced recovery of $\mathrm{BN}$-infected grapevines. However, the compatibility of these products and the treatment schedules used with integrated pest management programs, and the economic and environmental sustainability of these systems, are essential issues for the translation of these findings to large-scale applications. From a practical point of view, it should also be noted that the commercial product containing benzothiadiazole is not registered for use on grapevine in Europe. Also, commercial products containing phosetyl-Al have the requirement for a 40-day preharvest interval (with Chardonnay harvested in central-eastern Italy at approximately the middle of August, whereas the other cultivars are usually harvested in SeptemberOctober). Indeed, the commercial products containing GO1, $\mathrm{GO} 2$, and chitosan are registered as promoters of plant resistance and not as plant-protection products. Moreover, the mechanisms of action of these elicitors still remain to be defined. However, our studies have opened new perspectives for phytoplasma disease management, and demonstrate that the grapevine can be used as a model wood species to test this innovative strategy further.

\section{ACKNOWLEDGMENTS}

This study was carried out within the projects "Varenne" funded by the Fondazione Cariverona (Bando 2007), and MIUR PRIN 2005074429_002 "Factors associated with recovery in Bois noir affected vines in Central and Southern Adriatic sea coast and in Sardinia and search for innovative means to increase the phenomenon". We thank P. Biondini (Azienda Santa Casa di Loreto, Ancona, Italy), N. Petrelli (Montalto Marche, Ascoli Piceno, Italy), F. Patrizio, and M. Piergiacomi for technical assistance during the surveys.

\section{LITERATURE CITED}

1. Bautista-Baños, S., Hernández-Lauzardo, A. N., Velázquez-del Valle, M. G., Hernández-López, M., Ait Barka, E., Bosquez-Molina, E., and Wilson, C. L. 2006. Chitosan as a potential natural compound to control pre- and postharvest diseases of horticultural commodities. Crop Prot. 25:108-118.

2. Belli, G., Bianco P. A., and Conti, M. 2010. Grapevine yellows in Italy: Past, present and future. J. Plant Pathol. 92:303-326.

3. Bressan, A., and Purcell, A. H. 2005. Effect of benzothiadiazole on transmission of X-disease phytoplasma by the vector Colladonus montanus to Arabidopsis thaliana, a new experimental host plant. Plant Dis. 89:11211124.

4. Caudwell, A. 1961. Les phénomènes de rétablissement chez la flavescence dorée de la vigne. Ann. Epiphyt. 12:347-354.

5. Chiesa, S., Prati, S., Assante, G., Maffi, D., and Bianco, P. A. 2007. Activity of synthetic and natural compounds for phytoplasma control. Bull. Insectol. 60:313-314.

6. Conover, W. J, and Iman, L. R. 1981. Rank transformation as a bridge between parametric and nonparametric statistics. Am. Stat. 35:124-129.

7. Contaldo, N., Bertaccini, A., Paltrinieri, S., Windsor, H., M., and Windsor, G. D. 2012. Axenic culture of plant pathogenic phytoplasma. Phytopathol. Mediterr. 51:607-617.

8. Ćurković Perica, M. 2008. Auxin-treatment induces recovery of phytoplasma-infected Periwinkle. J. Appl. Microbiol. 105:1826-1834.

9. D'Amelio, R., Marzachì, C., and Bosco, D. 2010. Activity of benzothiadiazole on chrysanthemum yellows phytoplasma ('Candidatus Phytoplasma asteris') infection in daisy plants. Crop Prot. 29:1094-1099.

10. D'Amelio, R., Massa, N., Gamalero, E., D'Agostino G., Sampò, S., Berta, G., Faoro, F., Iriti, M., Bosco, D., and Marzachì, C. 2007. Preliminary results on the evaluation of the effects of elicitors of plant resistance on chrysanthemum yellows phytoplasma infection. Bull. Insectol. 60:317-318.

11. Endeshaw, S. T., Murolo, S., Romanazzi, G., and Neri, D. 2012. Effects of Bois noir phytoplasma infection on carbon assimilation, transpiration, and stomatal conductance of field grown grapevine (Vitis vinifera L.) cv. Chardonnay. Physiol. Plant. 145:286-295.

12. Feliziani, E., Santini, M., Landi, L., and Romanazzi, G. 2013. Pre and postharvest treatment with alternatives to synthetic fungicides to control postharvest decay of sweet cherry. Postharvest Biol. Technol. 78:133-138.

13. Garau, R., Sechi, S., Prota, V. A., and Moro, G. 2007. Productive parameters in Chardonnay and Vermentino grapevines infected with "Bois noir" and recovered in Sardinia. Bull. Insectol. 60:233-234.

14. Godard, J. F., Ziadi, S., Monot, C., Le Corre, D., and Silué, D. 1999. Benzothiadiazole (BTH) induces resistance in cauliflower (Brassica oleracea var. botrytis) to downy mildew of crucifers caused by Peronospora parasitica. Crop Prot. 18:397-405.

15. Gomez, L. D., Noctor, G., Knight, M. R., and Foyer, C. H. 2004. Regulation of calcium signalling and gene expression by glutathione. J. Exp. Bot. 55:1851-1859.

16. Heil, M., Hilpert, A., Kaiser, W., and Linsenmair, E. 2000. Reduced growth and seed set following chemical induction of pathogen defence: Does systemic acquired resistance (SAR) incur allocation costs? J. Ecol. 88:645-654.

17. Iriti, M., Castorina, G., Vitalini, S., Mignani, I., Soave, C., Fico, G., and Faoro, F. 2010. Chitosan-induced, ethylene-independent resistance does not reduce crop yield in bean plants. Biol. Control 54:241-247.

18. Iriti, M., and Faoro, F. 2003. Does benzothiadiazole-induced resistance increase fitness cost in bean? J. Plant Pathol. 85:265-270.

19. Landi, L., and Romanazzi, G. 2011. Seasonal variation of defence-related gene expression in leaves from Bois noir affected and recovered grapevines. J. Agric. Food Chem. 59:6628-6637.

20. Langer, M., and Maixner, M. 2004. Molecular characterization of grapevine-yellows-associated phytoplasmas of the stolbur group, based on RFLP-analysis of non-ribosomal DNA. Vitis 43:191-200.

21. Maixner, M. 2011. Recent advances in Bois noir research. Petria 21:95108.

22. Martelli, G. P., and Boudon-Padieu, E. 2006. Directory of infectious diseases of grapevines. Options Méditerr. B 55:157-194.

23. Morone, C., Boveri, M., Giosuè, S., Gotta, P., Rossi, V., Scapin, I., and Marzachì, C. 2007. Epidemiology of Flavescence Dorée in vineyards in Northwestern Italy. Phytopathology 97:1422-1427.

24. Murolo, S., Marcone, C., Prota, V., Garau, R., Foissac, X., and Romanazzi, G. 2010. Genetic variability of the stolbur phytoplasma vmp1 gene in grapevines, bindweeds and vegetables. J. Appl. Microbiol. 109: 2049-2059.

25. Musetti, R., Farhan, K., De Marco, F., Polizzotto, R., Paolacci, A., Ciaffi, M., Ermacora, P., Grisan, S., Santi, S., and Osler, R. 2013. Differentiallyregulated defence genes in Malus domestica during phytoplasma infection and recovery. Eur. J. Plant Pathol. 136:13-19. doi:10.1007/s10658-0120147-6 
26. Musetti, R., Marabottini, R., Badiani, M., Martini, M., Sanità di Toppi, L., Borselli, S., Borgo, M., and Osler, R. 2007. On the role of $\mathrm{H}_{2} \mathrm{O}_{2}$ in the recovery of grapevine (Vitis vinifera, cv. Prosecco) from Flavescence dorée disease. Funct. Plant Biol. 34:750-758.

27. Oostendorp, M., Kunz, W., Dietrich, B., and Staub, T. 2001. Induced disease resistance in plants by chemicals. Eur. J. Plant Pathol. 107:19-28.

28. Osler, R., Carraro, L., Loi, N., and Refatti, E. 1993. Symptom expression and disease occurrence of a yellows disease of grapevine in northeastern Italy. Plant Dis. 77:496-498.

29. Patui, S., Bertolini, A., Clincon, L., Ermacora, P., Braidot, E., Vianello, A., and Zancani, M. 2013. Involvement of plasma membrane peroxidases and oxylipin pathway in the recovery from phytoplasma disease in apple (Malus domestica). Physiol. Plant. 148:200-213. doi:10.1111/j13993054.2012.01708.x

30. Romanazzi, G., D'Ascenzo, D., and Murolo, S. 2009. Field treatment with resistance inducers for the control of grapevine Bois noir. J. Plant Pathol. 91:677-682.

31. Romanazzi, G., Mlikota Gabler, F., Margosan, D. A., Mackey, B. E., and Smilanick, J. L. 2009. Effect of chitosan dissolved in different acids on its ability to control postharvest gray mold of table grapes. Phytopathology 99:1028-1036.

32. Romanazzi, G., and Murolo, S. 2008. Partial uprooting and pulling to induce recovery in Bois noir infected grapevines. J. Phytopathol. 156:47-750.
33. Romanazzi, G., Musetti, R., Marzachì, C., and Casati, P. 2009. Induction of resistance in the control of phytoplasma diseases. Petria 19:113-129.

34. Salgado-Siclán, M. L., Rojas-Martínez, R., Zavaleta-Mejía, E., OchoaMartínez, D., Burgueño-Ferreira, J. Xoconostle-Cázares, B., and RuizMedrano, R. 2012. Differential accumulation of defense-related transcripts by inducers of resistance in Arabidopsis. J. Plant Pathol. Microbiol. 3:137.

35. Stadnik, M. J., and Buchenauer, H. 1999. Effects of benzothiadiazole, kinetin and urea on the severity of powdery mildew and yield of winter wheat. Z. Pflanzenkrankh. Pflanzenschutz 106:476-489.

36. Vallad, G. E., and Goodman, R. M. 2004. Systemic acquired resistance and induced systemic resistance in conventional agriculture. Crop Sci. 44:1920-1934.

37. Walters, D., Walsh, D., Newton, A., and Lyon, G. 2005. Induced resistance for plant disease control: Maximizing the efficacy of resistance elicitors. Phytopathology 95:1368-1373.

38. Wingate, V. P. M., Lawton, M. A., and Lamb, C. J. 1988. Glutathione causes a massive and selective induction of plant defence genes. Plant Physiol. 87:206-210.

39. Wu, W., Ding, Y., Wei, W., Davis, R. E., Lee, I.-M., Hammond, R. W., and Zhao, Y. 2012. Salicylic acid-mediated elicitation of tomato defence against infection by potato purple top phytoplasma. Ann. Appl. Biol. 161:36-45. 